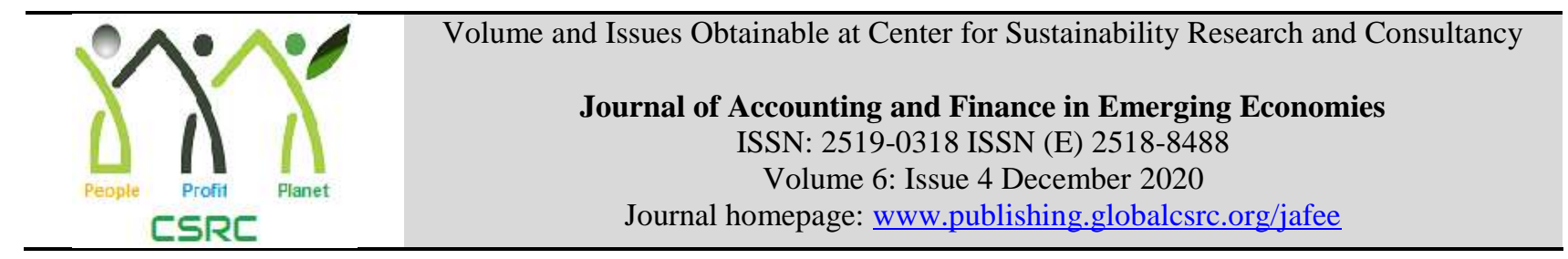

\title{
Financial Sustainability and Financial Performance: The Moderating Role of Type of Ownership in Pakistan
}

\author{
${ }^{1}$ Sarah Ahmed, ${ }^{2}$ S.M.Ali Tirmizi \\ ${ }^{1}$ Faculty of Management Sciences, Foundation University Islamabad, Pakistan, \\ sarah.qaim@fui.edu.pk \\ ${ }^{2}$ Assistant Professor, Foundation University Islamabad, Pakistan
}

\begin{tabular}{|c|c|}
\hline ARTICLE DETAILS & ABSTRACT \\
\hline History & The study is conducted with the objective to investigate the impact \\
\hline Revised format: November & of firm performance (FP) on financial sustainability (FS) in a \\
\hline 2020 & developing nation, Pakistan and additionally to see the moderating \\
\hline Available Online: December & role of type of ownership i.e. Institutional Ownership (IO) or \\
\hline 2020 & Managerial Ownership (MO) in the FP-FS relationship. Sample of \\
\hline Keywords & the study included all the non-financial firms listed on Pakistan \\
\hline Financial Sustainability, Firm & Stock Exchange PSX and time covered is from 2009-2018. In total \\
\hline Performance, Managerial & there are 2734 observations. Empirical results of the study suggests \\
\hline Ownership, Institutional & that FP has a positive relationship with FS but the relation is not \\
\hline Ownership, moderation. & significant. Moreover, findings indicate this relationship is \\
\hline JEL Classification: & significantly negatively moderated by Intuitional Ownership (IO) \\
\hline M40, M41 & $\begin{array}{l}\text { whereas the relationship is not significant under the moderation } \\
\text { impact of Managerial Ownership (MO). }\end{array}$ \\
\hline
\end{tabular}

\section{OPEN ACCESS}

(C) 2020 The authors, under a Creative Commons Attribution-

NonCommercial 4.0

Corresponding author's email address: sarah.qaim@ fui.edu.pk

Recommended citation: Ahmed, S., \& Tirmizi, S. M. A. (2020). Financial Sustainability and Financial Performance: The Moderating Role of Type of Ownership in Pakistan. Journal of Accounting and Finance in Emerging Economies, 6(4), 1181-1187

\section{Introduction}

At the present time, companies are demanded to operate in a sustainable manner in order to return more to the society in the form of better society, environment or financial input. Corporate sustainability ${ }^{1}$ studies are increasing in the literature. Moreover, it is difficult to go through a company's reports or websites without the reference to sustainable development or sustainability (Montiel \& DelgadoCeballos, 2014). Corporate sustainability has three dimensions i.e. social, environmental and economic aspect (Accenture, 2011). Financial sustainability of a company is related to the economic aspect of corporate sustainability. Financial sustainability is derived from the principle of value maximization for stakeholders by investing in best possible investments with an acceptable level of risk (Zabolotnyy \& Wasilewski, 2019). By applying the concept of sustainability, organizations are trying to cope up with the ups and down of economic development and organization of resources in the long term. Concept of financial sustainability is relatively recent in the literature (Lagoarde-Segot \& Paranque, 2018). 
Financial sustainability of a firm is defined as the potential to provide continuity of activities and to create value for owners in the long term, using optimal combination of investment and sources of financing (Zabolotnyy \& Wasilewski, 2019). The concept of financial sustainability caters the going concern principle of accounting and value maximization for stakeholders.

Despite many studies have been conducted to analyze the correlation between firm performance and corporate sustainability there is lack of research focused on evaluation of financial sustainability on firm level. (Diantimala, 2018). Moreover, importance of corporate governance factors for this relationship remains under investigative as well (Peng \& Yang, 2014). Studies related to moderating role of corporate governance are still unclear (Harjoto \& Jo, 2011). In this study, we focus on one aspect of corporate governance i.e. type of ownership: Institutional Ownership (IO) or Managerial Ownership (MO) and attempt to investigate how ownership as a moderator would affect the FP-FS relationship and in which direction.

This study is conducted in a developing country of Pakistan, as it is evident from the literature that studies about financial sustainability and sustainability in general, related to developing nations are very limited and there is a need to conduct such studies in developing countries (Grewatsch \& Kleindienst, 2017) the direction of the relationship could be different from developed nations. Moreover, ownership type demands further investigation because of the agency problem which arise due to conflict of interest between the management and the shareholders in emerging markets (Claessens, Djankov, Fan, \& Lang, 2002).

This study focuses on Pakistan, which is a developing country where there is weak protection for shareholders, problems related to corporate governance due to lack of transparency and ownership issues (Ararat \& Ugur, 2003). This can result in difference in direction of the developing country from a developed country. In country like Pakistan, government is more focused on developing policies to improve the current situation of the economy rather than long term impact. Research has shown that in a developing country low future orientation can have negative impact on firms in the longer run (Ararat, 2008). This study is expected to contribute towards the literature by: providing empirical data of FS-FP relationship, impact of corporate governance as a moderator in the FS-FP relationship. Thus the empirical analysis would be beneficial for policy implications, managers, and academicians. The rest of the paper is arranged as follows: the second section gives a review of the literature, third section explains the methodology used in this paper whereas results are provided in the fourth section. Lastly, paper concludes with the findings, limitation and future implications.

\section{Review of Literature}

Corporate governance, as the previous literature reveals has been studied numerous times, as a channel through which sustainability is influenced by firm performance. Number of proxies are used to measure corporate governance like CEO power ( $\mathrm{Li}, \mathrm{Li}, \&$ Minor, 2016), governance structure's (Giroud \& Mueller, 2011), mutual monitoring (Li Z. , 2014), CEO tournament (Coles, Li, \& Wang, 2017), compensation incentives (Core \& Guay, 1999), corporate governance policies (Aras \& Crowther, 2008) in the studies related to CSR, sustainability, corporate sustainability. A study conducted in Kenya on Micro Finance Institutions reveals that board size, CEO duality, composition of board and CEO gender have significant impact on financial sustainability of the institutions (Chenuos, Mohamed, \& Bitok, 2014). Corporate governance is associated with the procedures, processes, and practices through which organizations operate. These rules and procedures are to be followed and the manner in which they are followed determine the corporate governance of an organization. Goals of good governance are to use the resources in such an efficient manner that the interest of corporates are aligned with the interest of the society and the other stakeholders. Therefore, corporate governance is the connection between internal governance mechanisms of corporates and the society's way to make the corporate accountable (Deakin \& Hughes, 1997). Moreover, it helps the corporate to operate successfully in a society (Keasey, Thompson, \& Wright, 1997) and for longer period of time (Kontes, 2004). 
Long term endurance has become a challenge for every firm whether small, medium or a corporate, how businesses may respond to this challenge is very important for them to answer (Krechovska \& Prochazkova, 2014). Sustainability is the strategy for long term sustenance of the organizations comprising of three dimension i.e. economic, social and environmental. It has also been emphasized by some authors that economic dimension is the most desirable of the three as it makes the organizations financially strong and would avoid situations leading towards bankruptcy or shut down (Szekely \& Knirsch, 2005), (Gupta \& V. Kumar, 2013). Financial sustainability is covering the economic dimension of sustainability which is when a firm creates value for its stakeholder by maximizing the profits and minimizing the impact on the society. Researches have agreed on the multifaceted nature of financial sustainability, as it is linked to solvency, profitability and efficiency of an organization whether private or public (Diakoulaki, Mavrotas, \& Papayannakis, 1992), (Gryglewicz, 2011). Another study suggest that financial sustainability is about the financial viability or strength of the firm and it has a board spectrum when compared to firm performance (Matson, Thayer, \& Shaw, 2016). Numerous research studies have been conducted in this regard but there is still lack of research directed towards the methodology or measure of financial sustainability on a firm level (Zabolotnyy \& Wasilewski, 2019), (Jordão \& Almeida, 2017).

There is no confirmed direction of firm performance and sustainability relationship, it differs in different cultures and economic conditions, therefore there is no universally accepted direction of this relationship (Goyal, Rahman, \& Kazmi, 2013). Moreover, empirical evidence from developing and emerging countries is limited in literature (Grewatsch \& Kleindienst, 2017). Corporates are now improving their performance by striving for long term benefits (Chabowski, Mena, \& Gonzalez-Padron, 2011). Commitment of an organization for long term survival has now a strategic level importance and society expects an organization to live as a better citizen (Orsato, 2006).

In the context of a developing country, studies related to financial sustainability and corporate are limited and mainly conducted on financial sector (Rauf \& Mahmood, 2009), NGOs (Hussain, Shaheen, \& Shahid, 2018).

\section{Methodology}

\subsection{Sample and Data}

The population of this research is the non-financial sector of Pakistan, which consist of around 400 firms. Data was collected from 2010 till 2019. Data was extracted from financial statements of these firms which are listed with Pakistan Stock Exchange PSX. Firms with missing data were removed from the sample which reduced the data to 281 firms and 2734 observations for the sample period.

\subsection{Variables}

The dependent variable was financial sustainability calculated by Sustainable Growth Ratio (SGR) as calculated by (Amouzesh, Moeinfar, \& Mousavi, 2011). Independent variable in the study is firm performance which is measured by Tobin Q ratio. Type of ownership is taken as a moderator in the study. There are two types of ownership: Managerial ownership (MO) and Institutional Ownership (IO). Data regarding these variables were collected from financial statements. For Control variables of the study log of firm age was taken.

Table 1: Calculation Measures for the Variables

\begin{tabular}{ll}
\hline Variables & The rate of growth that a company can expect to see in the long term calculated by \\
SGR & multiplying a company's earnings retention rate by its return on equity. \\
The $\mathbf{Q}$ ratio, also known as Tobin's $\mathbf{Q}$, equals the market value of a company \\
divided by its assets' replacement cost. Thus, equilibrium is when market value \\
equals replacement cost.
\end{tabular}




\begin{tabular}{ll}
\hline Managerial Ownership & $\begin{array}{l}\text { Managerial ownership is measured as the percentage of equity shares owned by } \\
\text { directors' and their immediate families at the accounting year end. }\end{array}$ \\
Institutional Ownership & $\begin{array}{l}\text { Institutional ownership is the amount of a company's available stock owned by } \\
\text { mutual or pension funds, insurance companies, investment firms, private } \\
\text { foundations, endowments or other large entities that manage funds on behalf of } \\
\text { others. } \\
\text { Log of firm age }\end{array}$ \\
\hline
\end{tabular}

\subsection{Model}

To test the hypotheses of the study following model was developed:

$\mathrm{SGR}_{\mathrm{it}}=\beta \mathrm{o}+\beta 1 \mathrm{FP}_{\mathrm{it}}+\beta 2 \mathrm{FP}_{\mathrm{it}} \mathrm{XMO}_{\mathrm{it}}+\beta 3 \mathrm{X}_{\mathrm{it}}+\varepsilon_{\mathrm{it}} \quad$ equation 1

$$
\mathrm{SGR}_{\mathrm{it}}=\beta \mathrm{o}+\beta 1 \mathrm{FP}_{\mathrm{it}}+\beta 2 \mathrm{FP}_{\mathrm{it}} \mathrm{XIO}_{\mathrm{it}}+\beta 3 \mathrm{X}_{\mathrm{it}}+\varepsilon_{\mathrm{it}} \quad \text { equation } 2
$$

Where SGR (Sustainable Growth Rate Ratio) is the measure used to calculate the financial sustainability of the firm following (Amouzesh, Moeinfar, \& Mousavi, 2011). It is calculated by the following formula:

SGR= Retention Ratio* Return on Earnings

Whereas:

Retention ratio $=$ Retained earnings/Net income $* 100$

$\mathrm{ROE}=$ Net Income / Shareholders Equity

FP is the firm performance calculated through Tobin's Q. Formula for Tobin's Q is as follows:

Tobin's Q= Equity Market value+ Liability Market Value/ Total Asset Replacement Value.

MO is the managerial ownership which is derived from the annual financial data of each company.IO is the institutional ownership which is derived from the annual financial data of each company. FP X MO and FP X IO are the interaction terms used to calculate the moderating impact of ownership type on FP and FS relationship. X denotes the control variable which the log of firm age of the firm $i$ in year $t$. $\quad \beta_{1}$, $\beta_{2}, \beta_{3}$ are the vectors of the measures to be calculated and $\varepsilon$ is the error term.

\section{Results}

The following table shows the descriptive statistics of the variables of interest. Table shows the mean, normality of the data and the standard deviation along with the number of observations.

Table 2: Descriptive Statistics

\begin{tabular}{llllll}
\hline Variables & Mean & Skewness & Kurtosis & Std. Dev & Obs \\
\hline IO & 19843473 & 1.047823 & 6.306894 & 8.38 & 1844 \\
Log Firm Age & 2.804224 & -1.24746 & 3.088403 & 0.497 & 2870 \\
FP & 231000000 & 1.977534 & 4.421431 & 15.125 & 2734 \\
MO & 10207107 & 1.035595 & 1.447254 & 1.28 & 2870 \\
SGR & 872944.2 & 1.077137 & 1.796717 & 15.366 & 2631
\end{tabular}

Table 3 shows the Panel Least Squares, regression results for FP-FS relationship:

Table 3: Panel Least Squares

\begin{tabular}{lllll}
\hline Variable & Coefficient & Std. Error & $\boldsymbol{t}$-Statistic & $\boldsymbol{p}$-Value \\
\hline & & & & \\
C & -2.17 & 1.97 & -1.11 & 0.27 \\
FP & 0.00 & 0.00 & -0.77 & 0.44 \\
FP X IO & 0.00 & 0.00 & -4.79 & 0.00 \\
FP X MO & 0.00 & 0.00 & -0.03 & 0.98 \\
FIRM_AGE_LOG_AGE_ & 0.79 & 0.68 & 1.16 & 0.24 \\
\hline
\end{tabular}

The relationship between FP-FS is insignificant and negatively related. Therefore, FP has an insignificant impact on FS, showing if the firms performing better financially does not imply that it 
would get financial sustainability. Institutional ownership has a significant impact on the FP-FS relationship but the negative direction which shows that if the IO increases the FS would reduce. Moreover, it shows if shares of a firm are owned by other institutions it would have negative impact on its financial sustainability. MO does not have a significant on FP-FS relationship.

\section{Conclusion}

Limited number of studies have investigated the moderators for FP-FS relationship, this area need more research. In the context of a developing country the role of corporate governance factors affecting FPFS is again limited (Zabolotnyy \& Wasilewski, 2019), (Akben-Selcuk, 2019). This research was conducted with a purpose to fill the gap and to investigate the FP-FS relationship in the presence of a type of ownership as a moderator.

Findings from the study shows that there is no significant relationship between FP-FS in the nonfinancial firms in Pakistan. The sample had all the firms listed on PSX for the time period of 10 years from 2010-2019. This result supports the Neoclassical theory of the firm, which states that the main objective of the firm is to maximize profit. Backing the conventional theory of economics, the result supports that the main objective of a corporate is to earn profit and increase the worth of its shareholders. A study conducted in Turkey also showed that ownership has a negative impact on FPCSR relationship (Akben-Selcuk, 2019).

Another result from the study shows that ownership type has a negative but significant impact on FP-FS relationship in the form of IO as a moderator whereas it is insignificant in case of MO as the moderator between FP-FS relationship. The result is consistent with the empirical findings from (Peng \& Yang, 2014), (Ting \& Yin, 2018). The findings of the study would certainly add to the limited existing literature. Moreover, the negative affect of IO as a moderator would help the corporates to reduce IO in order to strengthen the value for shareholders. Findings can also help the policy makers, who are making policies for the corporates in the emerging countries. However, the study has also some limitations, firstly, data is collected from non-financial sectors only financial sectors could be included in the future studies for an overall view of the firms working in a country. Secondly, this study is conducted on data from a single country, Pakistan, more comprehensive study could be conducted in future by using data from more than one country.

Funding: This research received no external funding.

Conflicts of interest: The author declare no conflict of interest.

\section{References}

Accenture, C. I. (2011). Sustainability performance management: How CFOs can unlock value. London: Chartered Institute of Management Accountants.

Akben-Selcuk, E. (2019). Corporate Social Responsibility and Financial Performance: The Moderating Role of Ownership Concentration in Turkey. Sustainability, 11,3643, 1-10.

Amouzesh, N., Moeinfar, Z., \& Mousavi, Z. (2011). Sustainable Growth Rate and Firm Performance : Evidence From Iran Stock Exchange. International Journal of Business and Social Science Vol. 2 No. 23, 249- 255.

Ararat, M. (2008). A development perspective for "corporate social responsibility": Case of Turkey. Corporate Goverance International Journal of Business Society, 8, 271-285.

Ararat, M., \& Ugur, M. (2003). Corporate governance in Turkey: An overview and some policy recommendations. Corporate Governace International Journal Business Society, 3, 58-75.

Aras, G., \& Crowther, D. (2008). Governance and sustainability: An investigation into the relationship between corporate governance and corporate sustainability. Management Decision, Vol. 46 No. 3, 433-448, https://doi.org/10.1108/00251740810863870.

Chabowski, B., Mena, J., \& Gonzalez-Padron, T. (2011). The structure of sustainabilityresearch in marketing, 1958-2008: a basis for future research opportunities. Journal of the Academy of 
Marketing Science, Vol. 39 No. 1, 55-70.

Chenuos, N. K., Mohamed, A., \& Bitok, S. K. (2014). Effects of Corporate Governance on Micro Finance Institutions Financial Sustainability in Kenya . European Journal of Business and Management, Vol.6, No.30, ISSN 2222-1905 (Paper) ISSN 2222-2839 (Online).

Claessens, S., Djankov, S., Fan, J., \& Lang, L. (2002). Disentangling the incentive and entrenchment effects of large shareholdings. Journal of Finance, 57, 2741-2771.

Coles, J., Li, Z., \& Wang, A. (2017). Industry tournament incentives. . Review of Financial Studies. 31, $1418-1459$.

Core, J., \& Guay, W. (1999). The use of equity grants to manage optimal equity incentive levels. journal of Accounting and Economics, 28, 151-184.

Deakin, S., \& Hughes, A. (1997). Comparative corporate: An interdisciplinary agenda",. In In Enterprise and Community: New Directions in Corporate Governance, S. Deakin and A. Hughes (Eds.). . Oxford.: Blackwell Publishers.

Diakoulaki, D., Mavrotas, G., \& Papayannakis, L. (1992). A multicriteria approach for evaluating the performance of industrial firms. Omega 20, 467-474.

Diantimala, Y. (2018). The mediating effect of sustainability disclosure on the relationship between financialperformance and firm value. Journal of Accounting, Finance Auditing Studies, 4, , 32-48 .Giroud, X., \& Mueller, H. (2011). Corporate governance, product market competition, and equity prices. Journal of Finance,66, 563-600.

Goyal, P., Rahman, Z., \& Kazmi, A. (2013). Corporate sustainability performance and firm performance research: Literature review and future research agenda. Management Decision, Vol. 51 No. 2, 361-379. https://doi.org/10.1108/00251741311301867.

Grewatsch, S., \& Kleindienst, I. (2017). When does it pay to be good? Moderators and mediators in the corporate sustainability-corporate financial performance relationship: A critical review. Journal of Business Ethics, 145, 383-416.

Gryglewicz, S. (2011). A theory of corporate financial decisions with liquidity and solvency concerns. . Journal of Finance and Economics, 99, 365-384.

Gupta, S., \& V. Kumar. (2013). Sustainability as corporate culture of a brand for superior performance. Journal of World Business. 48, 311-320.

Harjoto, M., \& Jo, H. (2011). Corporate governance and CSR nexus. . Journal of Business Ethics, 100, 45-67.

Hussain, H., Shaheen, L., \& Shahid, M. A. (2018). Microfinance Ngos In Pakistan: Outreach And Sustainability. International Journal of Accounting and Financial Management Research (IJAFMR) , 17-26.

Jordão, R., \& Almeida, V. (2017). Performance measurement, intellectual capital and financial sustainability. Journal of Intellectual Capital, Vol. 18 No. 3, 643-666. https://doi.org/10.1108/JIC-11-2016-0115.

Keasey, K., Thompson, S., \& Wright, M. (1997). Corporate Governance: Economic and Financial Issues. . Norfolk.: Oxford University Press.

Kontes, P. (2004). A new look for the corporate center: reorganizing to maximize value. Journal of Business Strategy. 25, 18-24.

Krechovska, M., \& Prochazkova, P. T. (2014). Sustainability and its Integration into Corporate Governance Focusing on Corporate Performance Management and Reporting . Procedia Engineering 69, 1144 - 1151.

Lagoarde-Segot, T., \& Paranque, B. (2018). Finance and sustainability: From ideology to utopia. International Review of Financial Analysis, 55, 80-92.

Li, F., Li, T., \& Minor, D. (2016). A Test of Agency Theory: CEO Power, Firm Value, and Corporate Social Responsibility. International Journal of Management Finance12, . , 611-628.

Li, Z. (2014). Mutual monitoring and corporate governance. Journal of Banking and Finance. 45, , 255269.

Matson, J., Thayer, J., \& Shaw, J. (2016). Running a Food Hub: Assessing Financial Viability. Washington, DC, USA: United States Department of Agriculture. 
Montiel, I., \& Delgado-Ceballos, J. (2014). Defining and Measuring Corporate Sustainability: Are We There Yet? Organization \& Environment, 1-27, DOI: 10.1177/1086026614526413.

Neubaum, D. O., \& Zahra, S. A. (2006). Institutional ownership and corporate social performance: The moderating effects of investment horizon, activism, and coordination. . Journal of Management, $32,108-131$.

Orsato, R. (2006). Competitive environmental strategies: when does it pay to be Green? . California Management Review, Vol. 48 No. 2, 127-143.

Peng, C., \& Yang, M. (2014). The effect of corporate social performance on financial performance: The moderating effect of ownership concentration. Journal of Business Ethics, 123, 171-182.

Peng, C., \& Yang, M. (2014). The effect of corporate social performance on financial performance: The moderating effect of ownership concentration. . Journal of Business Ethics, 123, 171-182.

Rauf, S. A., \& Mahmood, T. (2009). Growth And Performance Of Microfinance In Pakistan. Pakistan Economic and Social Review, Vol. 47, No. 1, 99-122.

Szekely, F., \& Knirsch, M. (2005). Responsible Leadership and Corporate Social Responsibility: Metrics for Sustainable Performance. European Management Journal. 23, 628 - 647.

Ting, P., \& Yin, H. (2018). How do corporate social responsibility activities affect performance? The role of excess control right. . Corporate Social Responsibility and Environmental Management, $25,1320-1331$.

Zabolotnyy, S., \& Wasilewski, M. (2019). The Concept of Financial Sustainability Measurement: A Case of Food Companies from Northern Europe. Sustainability 11(18), DOI: $10.3390 /$ su11185139. 